Захаренко Людмила Миколаївна кандидат психологічних наук, старший науковий співробітник наукової лабораторії 3 проблем психологічного забезпечення та психофізіологічних досліджень, Національна академія внутрішніх справ, пл. Солом'янська, 1, м. Київ, 03035, тел.: (044) 520-06-74, e-mail: zakharenko-luda@ukr.net, https://orcid.org/0000-0002-2121-0862

Юрченко-Шеховцова Тетяна Іванівна кандидат психологічних наук, науковий співробітник наукової лабораторії 3 проблем психологічного забезпечення та психофізіологічних досліджень, Національна академія внутрішніх справ, пл. Солом'янська, 1, м. Київ, 03035, тел.: (044) 520-06-74, e-mail: tanusha2307@ukr.net, https://orcid.org/0000-0001-6541-3410

\title{
ВІДКРИТІСТЬ НОВОМУ ДОСВІДУ ЯК ОСОБИСТІСНА ЯКІСТЬ НАУКОВО-ПЕДАГОГІЧНИХ ПРАЦІВНИКІВ
}

Анотація. У сучасному світі важливою особистісною якістю людини є відкритість новому досвіду, що дозволяє їй успішно адаптуватися до навколишніх змін, творчо підходити до вирішення нагальних питань життєдіяльності, брати відповідальність за своє життя. Науково-педагогічні працівники повинні бути відкритими до пізнання нового, адже вони за специфікою своєї професійної діяльності повинні опанувати нові форми, методи та засоби навчання та активно застосовувати їх в інноваційно-креативному освітньому просторі. Метою дослідження стало емпіричне вивчення особистісних характеристик науково-педагогічних працівників з різними рівнями відкритості новому досвіду. У дослідженні використані структурно-логічний метод, методи емпіричного психологічного дослідження (тестування), порівняльного аналізу. Емпірична база дослідження: 65 науково-педагогічних працівників, які працюють у закладах вищої освіти із специфічними умовами навчання, що здійснюють підготовку поліцейських. Наукова новизна. У ході дослідження було визначено, що науково-педагогічні працівники з різними рівнями відкритості новому досвіду схожі за показниками екстраверсії, спонтанності, ригідності, тривожності, інтроверсії, толерантності до невизначеності, внутрішньо-особистісного аспекту емоційного інтелекту, але відрізняються за показниками сенситивності та емоційної лабільності (межі норми або помірної вираженості), поступливості (конформізм/нонконформізм), показниками шкал міжособистісного аспекту емоційного інтелекту (середня чи низька вираженість його властивостей). Відкритість науково-педагогічних працівників новому 
досвіду у професійній діяльності зумовлює більшу сконцентрованість на накопиченні особистого досвіду вирішення завдань навчальної, методичної, наукової, організаційної, службової діяльності, але призводить до зменшення уваги на емоційному компоненті міжособистісної взаємодії. Висновки. Відкритість науково-педагогічних працівників новому досвіду проявляється у професійній діяльності при вирішенні ситуацій невизначеності та у міжособистісній взаємодії з учасниками освітнього процесу.

Ключові слова: відкритість новому досвіду, науково-педагогічні працівники.

Zakharenko Liudmyla Mykolaivna $\mathrm{Ph}$. D. in Psychology, senior research fellow, scientific laboratory on psychological support and psychophysiological research of the National Academy of Internal Affairs, Solomianska Square, 1, Kiev, 03035. tel.: (044) 520-06-74, e-mail: zakharenko-luda@ukr.net, https://orcid.org/0000-0002-2121-0862.

Yurchenko-Shekhovtsova Tetiana Ivanivna Ph. D. in Psychology, research fellow, scientific laboratory on psychological support and psychophysiological research of the National Academy of Internal Affairs, Solomianska Square, 1, Kiev, 03035, tel.: (044) 520-06-74, e-mail: tanusha2307@ukr.net, https://orcid.org/0000-0001-6541-3410.

\section{OPENNESS TO NEW EXPERIENCE AS A PERSONAL QUALITY OF SCIENTIFIC AND PEDAGOGICAL STAFF}

Abstract. Novaday an important personal quality of a person is openness to new experiences, which allows adapting successfully to environmental changes, to be creative in addressing pressing issues of life, to take responsibility for own lives. Scientific and pedagogical staff should be open to get to know new things, because they, according to the peculiarities of their professional activities, shell master new forms, methods and means of teaching and actively apply them in the innovative and creative educational space.

The aim of this research was to study empirically the personal characteristics of scientific and pedagogical staff with different levels of openness to new experiences. The structural-logical method, methods of empirical psychological research (testing), comparative analysis were used in this research.

Empirical basis of the research: 65 scientific and pedagogical staff that works in higher education institutions with specific training conditions, which train police officers. Scientific novelty. The study found that scientific and pedagogical staff with different levels of openness to new experiences are similar in indicators of extraversion, spontaneity, rigidity, anxiety, introversion, tolerance for uncertainty, intrapersonal aspect of emotional intellect, but differ in indicators of sensitivity and emotional lability (limits of norm or moderate expression), compliance (conformism / nonconformism), indicators of scales of the interpersonal aspect of emotional intellect 
(medium or low expression of its qualities). The openness of scientific and pedagogical staff to new experience in professional activities leads to a greater focus on the accumulation of personal experience in solving problems of educational, methodological, scientific, organizational and official activities, but reduces attention to the emotional component of interpersonal interaction. Conclusions. The openness of scientific and pedagogical staff to new experiences is expressed in professional activities in solving situations of uncertainty and in interpersonal interaction with participants in the educational process.

Keywords: openness to new experience, scientific and pedagogical staff.

Постановка проблеми. У сучасному світі важливою особистісною якістю людини є відкритість новому досвіду, що дозволяє їй успішно адаптуватися до навколишніх змін, творчо підходити до вирішення нагальних питань життєдіяльності, брати відповідальність за своє життя.

Формування єдиного освітнього простору як інтегративної системи в інформаційному суспільстві висуває нові вимоги до учасників освітнього процесу. Науково-педагогічні працівники закладів вищої освіти повинні бути професійно компетентними та відкритими новому досвіду. Згідно з ст. 55 Закону України «Про вищу освіту» науково-педагогічні працівники провадять за основним місцем роботи у закладах вищої освіти навчальну, методичну, наукову та організаційну діяльність [1]. Вони мають право на академічну свободу та академічну мобільність; право обирати методи та засоби навчання, що забезпечують високу якість навчального процесу; підвищення свого професійного рівня тощо. Вони зобов'язані забезпечувати викладання дисциплін на високому рівні, провадити наукову діяльність; підвищувати професійний рівень, педагогічну майстерність, наукову кваліфікацію; дотримуватися в освітньому процесі та науковій (творчій) діяльності академічної доброчесності та забезпечувати іiі дотримання здобувачами вищої освіти тощо.

На посади науково-педагогічних працівників закладів вищої освіти із специфічними умовами навчання, які здійснюють підготовку поліцейських, можуть призначатися поліцейські, які відповідають професійним, освітнім і кваліфікаційним вимогам для зайняття посади, із залишенням їх на службі в поліції [2]. За специфікою своєї професійної діяльності науково-педагогічні працівники повинні бути відкритими до пізнання нового, опанувати нові форми, методи, засоби навчання, активно застосовувати їх в інноваційно-креативному освітньому просторі.

Аналіз останніх досліджень і публікацій. Згідно з науковими поглядами дослідників відкритість новому досвіду $є$ здатністю самоактуалізованої особистості [9]; важливим компонентом іiі творчого потенціалу [6, с. 182], внутрішньою готовністю до розвитку, змін, сприйняття нового.

На основі теоретичного аналізу феномену «відкритість новому досвіду» 
(openness to experience) можна визначити, що дана характеристика включає у себе естетичну чутливість, увагу до почуттів інших, гнучкість розуму, незалежність у судженнях, наполегливість, креативність, позитивні емоційні переживання (зокрема, здивування, радість, почуття естетичного захоплення); проявляється у відкритості, сприйнятливості до будь-якого виду знань, готовності до різних видів активності; вказує на здатність сприймати нові ідеї та комфортно відчувати себе у новому середовищі, сприяє продуктивній творчості; асоціюється з успіхом у роботі з акцентом на інноваціях тощо [6; 7; 8; 9; $10 ; 11]$.

Відкритість новому досвіду має різні ступені вираженості та проявляється у творчому мисленні на основі пізнавальних здібностей, прагненню до творчості та спонтанності, що визначає якісно нові способи вирішення творчих завдань i особисту відповідальність за зміни, є проявом професіоналізму [8; 9; 10].

Відкритість новому досвіду науково-педагогічних працівників закладів вищої освіти сприятиме підвищенню їх креативних компетенцій, ефективній професійній діяльності, самоактуалізації, управлінню динамікою власних життєво-професійних можливостей, задоволення від процесу професійної діяльності.

Мета статті - емпіричне вивчення особистісних характеристик науковопедагогічних працівників з різними рівнями відкритості новому досвіду.

Виклад основного матеріалу. У дослідженні використані адаптовані україномовні варіанти психодіагностичних методик:

1) «Опитувальник великої п’ятірки» (адаптація Барка В. І., Остаповича В. П., Барка В. В. (2018) англомовного «Опитувальника великої п’ятірки» («Big Five Inventory») О. Джона, Л. Наумана, С. Сото) [6];

2) «Опитувальник толерантності до невизначеності» (адаптація Барка В. І., Барка В. В., Кирієнко Л. А. (2019) англомовного «Опитувальника толерантності до невизначеності» («Tolerance Ambiguily Scale» С. Баднера) [3];

3) «Опитувальник рівня і структури емоційного інтелекту» (адаптація Барка В. І., Остаповича В. П., Олешка П. С. (2019) російськомовної «Методики эмоционального интеллекта» М. Манойлової) [4];

4) «Індивідуально-типологічний опитувальник» (адаптація Білогурової С. В., Барка В. І., Барка В. В., Кирієнко Л. А. (2017) російськомовної методики «Индивидуальный-типологический опросник» Л. М. Собчик) [5].

У дослідженні використовувались структурно-логічний метод, методи емпіричного психологічного дослідження (тестування), порівняльного аналізу. Для обробки результатів дослідження використано описову статистику, однофакторний аналіз, t-критерій Стьюдента, r-коефіцієнт кореляції Пірсона. 
Статистична обробка даних проводилася 3 допомогою функцій та формул версії Excel, яка входить у програмний пакет Microsoft Office 2010.

Емпірична база дослідження (вибірка): 65 науково-педагогічних працівників, які працюють у закладах вищої освіти із специфічними умовами навчання, що здійснюють підготовку поліцейських. Вони мають науковий ступінь та вчене звання.

\section{Завдання дослідження:}

1) дослідити властивості емоційного інтелекту та рівень їх розвитку у респондентів із різними рівнями відкритості новому досвіду;

2) визначити індивідуально-типологічні властивості респондентів iз різними рівнями відкритості новому досвіду;

3) дослідити особливості ставлення респондентів із різними рівнями відкритості новому досвіду до ситуацій невизначеності;

4) описати особистісні характеристики науково-педагогічних працівників із різними рівнями відкритості новому досвіду.

Гіпотеза дослідження: відкритість новому досвіду є особистісною якістю науково-педагогічних працівників, що проявляється у їх професійній діяльності у міжособистісному спілкуванні та визначає ставлення до ситуацій невизначеності.

Виклад основного матеріалу. За допомогою методики «Опитувальник великої п'ятірки» було визначено кількісні показники екстраверсії, нейротизму, поступливості, сумлінності й відкритості досвіду та рівні їх розвитку, а також побудовано п’ятифакторну модель (рис. 1).

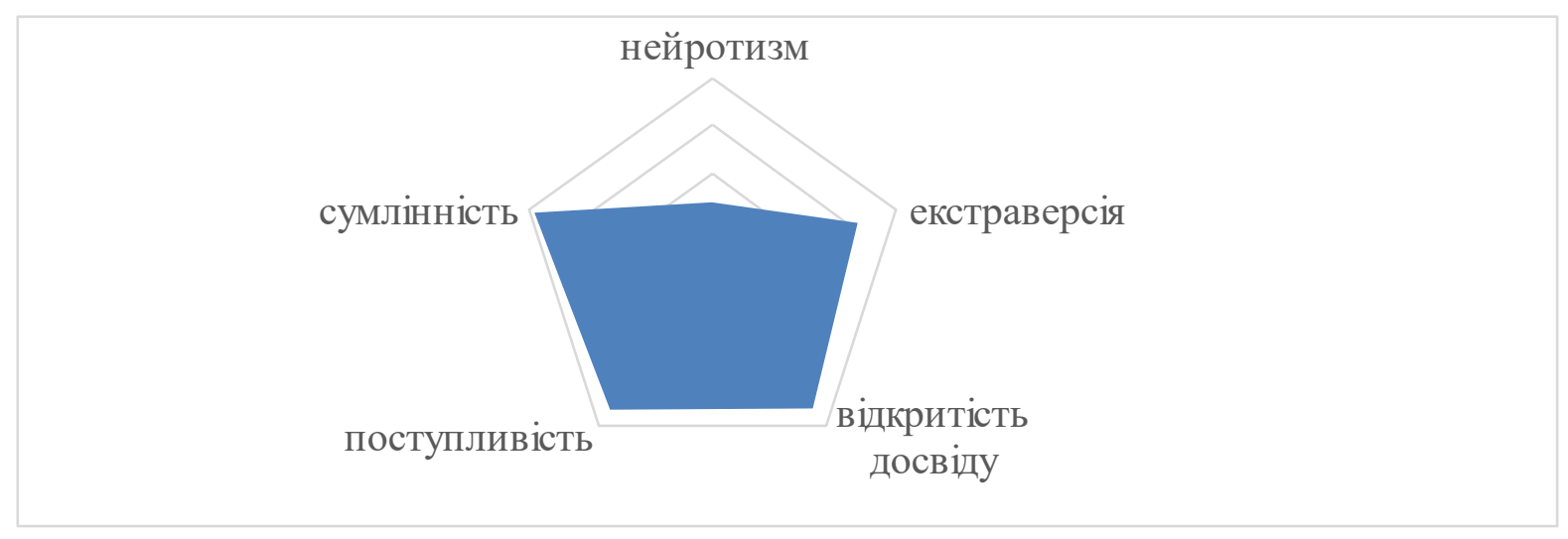

Рис. 1. П'ятифакторна модель (за шкалами «Опитувальника великої n'ятірки»).

Згідно 3 отриманими даними розподіл кількісних показників за шкалами опитувальника набирає мінімальних та максимальних значень від 8 до 47 балів, що дозволяє визначити рівень розвитку кожного особистісного фактору (див. табл. 1). 
Табличя 1

Рівні розвитку психологічних показників у вибірці за шкалами «Опитувальника великої п'ятірки» (кількість осіб)

\begin{tabular}{|l|l|l|l|l|l|}
\hline & Екстраверсія & Поступливість & Сумлінність & Нейротизм & $\begin{array}{l}\text { Відкритість } \\
\text { досвіду }\end{array}$ \\
\hline Високий рівень & - & 8 & 22 & - & 3 \\
\hline Середній рівень & $\mathbf{5 6}$ & $\mathbf{4 8}$ & $\mathbf{3 9}$ & - & $\mathbf{4 8}$ \\
\hline Низький рівень & 9 & 9 & 4 & 65 & 14 \\
\hline
\end{tabular}

Згідно 3 отриманими даними респондентам характерний низький рівень тривожності, середня чи низька екстравертованість, різні рівні прояву поступливості, сумлінності, відкритості новому досвіду.

За допомогою однофакторного дисперсійного аналізу Р. Фішера було визначено, що за психологічними показниками респонденти 3 різним рівнем відкритості досвіду статистично значимо відрізняються $(\mathrm{F}=1,703 ; \mathrm{df}=48 ; \mathrm{p}=0,002)$.

Відповідно до рівня відкритості новому досвіду респонденти були розподілені у три групи:

1) 3 високим рівнем відкритості новому досвіду (характерні низька тривожність, середня екстравертованість, висока чи середня поступливість, різні рівні прояву сумлінності);

2) 3 середнім рівнем відкритості новому досвіду (притаманні середня чи низька екстравертованість, різні рівні прояву поступливості та сумлінності);

3) 3 низьким рівнем відкритості новому досвіду (характерні низька тривожність, середні чи низькі екстравертованість та поступливість, різні рівні прояву сумлінності).

Встановлено, що високий рівень відкритості новому досвіду мають 3 осіб, більшості респондентів (48 осіб) характерний рівень середній рівень відкритості досвіду, а низький - 14 осіб.

За допомогою параметричного статистичного $\mathrm{t}$-критерію Стьюдента встановлено статистично значимі відмінності особистісних показників респондентів 3 різними рівнями відкритості досвіду. Отримані дані представлені у таблиці 2.

Таблиця 2

Відмінності психологічних показників респондентів 3 різними рівнями відкритості досвіду (за шкалами «Опитувальника великої п’ятірки)»

\begin{tabular}{|l|l|l|l|l|}
\hline & Екстраверсія & Поступливість & Сумлінність & Нейротизм \\
\hline Високий рівень & $36,33 \pm 0,57$ & $37,00 \pm 3,61$ & $38,00 \pm 6,56$ & $15,00 \pm 5,29$ \\
\hline Середній рівень & $32,27 \pm 3,51$ & $35,77 \pm 4,52$ & $39,33 \pm 3,83$ & $13,50 \pm 3,36$ \\
\hline Низький рівень & $28,86 \pm 2,68$ & $36,57 \pm 2,62$ & $36,21 \pm 4,25$ & $15,86 \pm 4,04$ \\
\hline $\mathrm{p}$ (високий-середні рівні) & $\mathrm{p}=\mathbf{0 , 0 2 3}$ & $\mathrm{p}=0,895$ & $\mathrm{p}=0,447$ & $\mathrm{p}=0,687$ \\
\hline $\mathrm{p}$ (середній-низький рівні) & $\mathrm{p}=\mathbf{0 , 0 1 0}$ & $\mathrm{p}=0,328$ & $\mathrm{p}=0,060$ & $\mathrm{p}=0,227$ \\
\hline $\mathrm{p}$ (високий - низький рівні) & $\mathrm{p}=\mathbf{0 , 0 1 3}$ & $\mathrm{p}=0,786$ & $\mathrm{p}=0,207$ & $\mathrm{p}=0,463$ \\
\hline
\end{tabular}


Згідно 3 представленими у таблиці даними опитані груп статистично значимо відрізняться за показниками екстраверсії: у осіб з високим рівнем відкритості досвіду цей показник вищий $(\mathrm{p} \leq 0,05)$, а у осіб із низьким рівнем відкритості досвіду - нижчий $(\mathrm{p} \leq 0,01)$. Відповідно до «коридору» середніх значень [6] середній рівень екстраверсії мають особи з високим і середнім рівнями відкритості досвіду, а середній та низький рівні - особи з низьким рівнем відкритості досвіду. Решта психологічних показників не відрізняються.

За методикою «Індивідуально-типологічний опитувальник» (далі - ITO) отримано результати за шкалами вимірювання індивідуально-типологічних тенденцій. Інтерпретація отриманих даних відбувалася відповідно до «коридору» середніх значень за шкалами методики ITO [5, с. 226].

За допомогою параметричного статистичного $\mathrm{t}$-критерію Стьюдента встановлено статистично значимі відмінності психологічних показників респондентів з різними рівнями відкритості досвіду. Отримані дані представлені у таблиці 3.

\section{Відмінності психологічних показників респондентів}

Таблиия 3

\section{з різними рівнями відкритості досвіду (методика ITO)}

\begin{tabular}{|c|c|c|c|c|c|c|c|c|}
\hline & 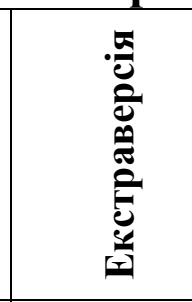 & 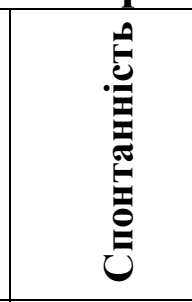 & 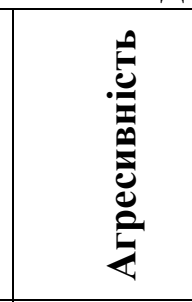 & : & 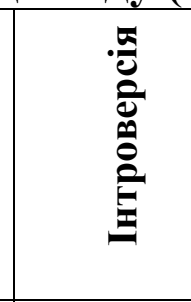 & 苞 & 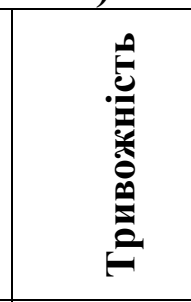 & 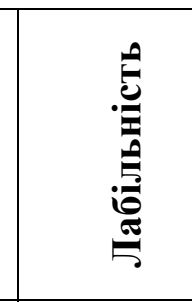 \\
\hline $\begin{array}{l}\text { Високий } \\
\text { рівень }\end{array}$ & $7,67 \pm 0,58$ & $5,33 \pm 0,58$ & $5,00 \pm 2,52$ & $5,67 \pm 1,53$ & $1,67 \pm 2,08$ & $5,00 \pm 1,73$ & $4,67 \pm 2,08$ & $7,00 \pm 1,00$ \\
\hline $\begin{array}{l}\text { Середній } \\
\text { рівень }\end{array}$ & $7,04 \pm 1,99$ & $5,83 \pm 1,34$ & $4,58 \pm 1,11$ & $5,31 \pm 1,63$ & $2,48 \pm 1,77$ & $5,10 \pm 1,32$ & $2,94 \pm 1,26$ & $6,23 \pm 1,06$ \\
\hline $\begin{array}{l}\text { Низький } \\
\text { рівень }\end{array}$ & $6,21 \pm 1,67$ & $4,00 \pm 1,18$ & $3,07 \pm 1,44$ & $4,36 \pm 1,34$ & $4,64 \pm 2,53$ & $5,43 \pm 1,28$ & $3,64 \pm 1,65$ & $5,57 \pm 1,16$ \\
\hline $\begin{array}{l}\text { p (вис.- } \\
\text { сер. } \\
\text { рівні) }\end{array}$ & $p=0,930$ & $p=0,914$ & $p=0,979$ & $p=0,168$ & $p=0,628$ & $p=0,328$ & $p=0,540$ & $p=0,429$ \\
\hline $\begin{array}{l}\text { p (сер.- } \\
\text { низ. } \\
\text { рівні) }\end{array}$ & $\mathrm{p}=1,326$ & $p=0,389$ & $p=0,313$ & $p=0,914$ & $p=0,181$ & $p=5,609$ & $p=3,881$ & $p=\mathbf{0 , 0 0 0}$ \\
\hline \begin{tabular}{|l|}
$\mathrm{p}$ (вис. - \\
низ. \\
рівні) \\
\end{tabular} & $p=0,079$ & $p=0,645$ & $p=0,645$ & $p=0,242$ & $p=0,839$ & $\mathrm{p}=\mathbf{0 , 0 0 2}$ & $\mathrm{p}=0,226$ & $\mathrm{p}=0,241$ \\
\hline
\end{tabular}

За допомогою порівняння середніх значень індивідуально-типологічних показників було визначено, що респонденти з різним рівнем відкритості досвіду статистично значимо відрізняються за показниками сенситивності $(p=0,000)$ та 
лабільності ( $\mathrm{p}=0,002)$ : сензитивність у межах норми, помірно виражена емоційна лабільність характерні для осіб із високим та середнім рівнями відкритості досвіду; а для осіб із низьким рівнем відкритості досвіду - помірно виражена сензитивність, емоційна лабільність - у межах норми. Решта психологічних показників не відрізняються.

За результатами дослідження за методикою «Опитувальник толерантності до невизначеності» відповідно до «коридору» середніх значень [3, с. 230] визначено особливості розвитку толерантності до невизначеності (за шкалами опитувальника) респондентів 3 різними рівнями відкритості новому досвіду. Отримані дані подано у таблиці 4.

Таблиияя 4

Рівні розвитку толерантності до невизначеності у вибірці (кількість осіб)

\begin{tabular}{|l|c|c|c|c|}
\hline & Заг. показник & Новизна & Складність & Нерозв'язність \\
\hline Високий рівень & 6 & 4 & 40 & 2 \\
\hline Середній рівень & 59 & 60 & 25 & 62 \\
\hline Низький рівень & - & 1 & - & 1 \\
\hline
\end{tabular}

Відповідно до табличних даних респондентам властива толерантність до невизначеності високого (6 осіб) та середнього (59 осіб) рівнів. За шкалою «Складність» більшість респондентів (40 осіб) виявили високий рівень толерантності до невизначеності, що визначає їх ставлення до складних ситуацій як можливості розвитку. На середньому рівні толерантності майже всі респонденти (60 і 62 особи відповідно) поведуть себе у ситуаціях новизни та нерозв'язаності. Низький рівень ставлення до невизначеності не притаманний нікому із респондентів, хоча у ситуаціях новизни чи нерозв'язаності поставлених завдань можливі прояви інтолерантності у двох осіб.

Отримані середньогрупові показники (за шкалами опитувальника) толерантності до невизначеності респондентів з різними рівнями відкритості новому досвіду представлені у таблиці 5.

Таблиця 5

Відмінності показників толерантності до невизначеності респондентів 3 різними рівнями відкритості досвіду

\begin{tabular}{|l|c|c|c|c|}
\hline & Заг. показник & Новизна & Складність & Нерозв'язність \\
\hline Високий рівень & $74,67 \pm 11,24$ & $19,00 \pm 1,73$ & $43,33 \pm 9,45$ & $12,33 \pm 3,51$ \\
\hline Середній рівень & $66,17 \pm 6,90$ & $15,90 \pm 4,06$ & $37,99 \pm 4,01$ & $12,31 \pm 2,10$ \\
\hline Низький рівень & $65,29 \pm 6,78$ & $14,86 \pm 2,82$ & $37,86 \pm 4,02$ & $12,57 \pm 2,17$ \\
\hline $\mathrm{p}$ (високий-середні рівні) & $\mathrm{p}=0,069$ & $\mathrm{p}=0,139$ & $\mathrm{p}=0,071$ & $\mathrm{p}=0,835$ \\
\hline $\mathrm{p}$ (середній-низький рівні) & $\mathrm{p}=0,857$ & $\mathrm{p}=0,439$ & $\mathrm{p}=0,425$ & $\mathrm{p}=0,879$ \\
\hline $\mathrm{p}$ (високий - низький рівні) & $\mathrm{p}=0,568$ & $\mathrm{p}=0,862$ & $\mathrm{p}=0,363$ & $\mathrm{p}=0,576$ \\
\hline
\end{tabular}

Відповідно до отриманих даних респонденти 3 різним рівнем відкритості 
новому досвіду не відрізняються за загальним показником і показниками шкалам толерантності до невизначеності $(\mathrm{p} \geq 0,05)$. Їм характерні середній рівень толерантності до невизначеності, зокрема високий рівень толерантності у ситуаціях складності, середній - у ситуаціях новизни та нерозв'язаності.

Отже, у ситуаціях професійної діяльності, що характеризуються невизначеністю, респонденти здатні вирішувати нерозв'язані чи нові завдання, хоча можуть проявити прагнення до ясності у зв'язку із цим, але найефективніше та найпродуктивніше вони проявляють себе при розв'язанні складних завдань як можливості креативного осмислення та набуття нового досвіду.

Для оцінювання рівня і структури емоційного інтелекту респондентів було використано «Опитувальник рівня і структури емоційного інтелекту».

Відповідно до отриманих результатів діапазон середньогрупових значень за шкалами методики коливається від -1,11 балів до 2,48 балів, що свідчить про середній рівень розвитку емоційного інтелекту респондентів. Внутрішньоособистісний і міжособистісний аспекти (інтегральні індекси 86 балів і 136 балів відповідно) у структурі емоційного інтелекту респондентів представлені неоднаково. Інтегральний показник емоційного інтелекту - 222 бали.

За допомогою параметричного статистичного t-критерію Стьюдента було визначено відмінності у групах 3 різними рівнями відкритості досвіду за показниками шкал внутрішньо-особистісного та міжособистісного аспектів емоційного інтелекту. Отримані дані представлені у таблиці 6.

Табличя 6

Відмінності показників емоційного інтелекту респондентів з різними рівнями відкритості досвіду

\begin{tabular}{|l|c|c|c|c|}
\hline & \multicolumn{2}{|l|}{ Внутрішньо-особистісний аспект } & \multicolumn{2}{|c|}{ Міжособистісний аспект } \\
\cline { 2 - 5 } & $\begin{array}{l}\text { Усвідомлення } \\
\text { своїх емоцій i } \\
\text { почуттів }\end{array}$ & $\begin{array}{l}\text { Управління } \\
\text { своїми емоціями } \\
\text { та почуттями }\end{array}$ & $\begin{array}{l}\text { Усвідомлення } \\
\text { емоцій та } \\
\text { почуттів інших }\end{array}$ & $\begin{array}{l}\text { Управління } \\
\text { емоціями та } \\
\text { почуттями інших }\end{array}$ \\
\hline Високий рівень & $-1,00 \pm 3,61$ & $-5,00 \pm 2,00$ & $2,00 \pm 3,64$ & $-2,67 \pm 4,51$ \\
\hline Середній рівень & $2,69 \pm 3,10$ & $-0,75 \pm 3,26$ & $2,98 \pm 3,26$ & $0,83 \pm 2,96$ \\
\hline Низький рівень & $2,29 \pm 2,43$ & $-1,50 \pm 2,98$ & $0,21 \pm 1,81$ & $-1,14 \pm 1,75$ \\
\hline $\begin{array}{l}\mathrm{p} \text { (високий- } \\
\text { середні рівні) }\end{array}$ & $\mathrm{p}=0,224$ & $\mathrm{p}=0,072$ & $\mathrm{p}=0,636$ & $\mathrm{p}=0,192$ \\
\hline $\begin{array}{l}\mathrm{p} \text { (середній- } \\
\text { низький рівні) }\end{array}$ & $\mathrm{p}=0,897$ & $\mathrm{p}=0,965$ & $\mathrm{p}=\mathbf{0 , 0 0 1}$ & $\mathrm{p}=0,295$ \\
\hline $\begin{array}{l}\mathrm{p} \text { (високий - } \\
\text { низький рівні) }\end{array}$ & $\mathrm{p}=0,124$ & $\mathrm{p}=0,074$ & $\mathrm{p}=\mathbf{0 , 0 1 1}$ & $\mathrm{p}=\mathbf{0 , 0 3 9}$ \\
\hline
\end{tabular}

Відповідно до даних таблиці респонденти 3 різними рівнями відкритості досвіду схожі за показниками внутрішньо-особистісного аспекту емоційного інтелекту: показники середніх значень та стандартних відхилень вказують на середній рівень усвідомлення своїх емоцій, середній та низький рівні управління 
ними (діапазон середніх значень за шкалами коливається від - 7 до +5,79 балів).

Респонденти 3 різними рівнями відкритості досвіду відрізняються за показниками міжособистісного аспекту емоційного інтелекту. Їм притаманний середній рівень розуміння чужих емоцій та управління ними, проте особи 3 високим рівнем відкритості новому досвіду також можуть проявити низький рівень управління емоціями співрозмовника. Особи 3 високим та середнім рівнями відкритості досвіду можуть краще зрозуміти емоції та почуття співрозмовника, ніж особи з низьким рівнем відкритості досвіду $(\mathrm{p} \leq 0,01)$. Особи 3 середнім та низьким рівнями відкритості досвіду можуть краще управляти станом іншої людини для гармонізації стосунків $(\mathrm{p} \leq 0,05)$, на відміну від осіб з високим рівнем відкритості досвіду.

Проведений кореляційний аналіз за допомогою r-критерію Пірсона дозволив визначити силу та напрям інтеркореляційних взаємозв'язків показників шкал методики «Опитувальник великої п’ятірки» 3 іншими психологічними показниками (таблиця 7).

Таблиия 7

Інтеркореляційні взаємозв'язки шкал методики «Опитувальник великої п'ятірки» 3 іншими психологічними показниками (r-кореляції Пірсона)

\begin{tabular}{|l|c|c|c|c|c|}
\hline & $\begin{array}{l}\text { Екстравер } \\
\text { сія }\end{array}$ & $\begin{array}{c}\text { Поступли } \\
\text { вість }\end{array}$ & Сумлінність & Нейротизм & $\begin{array}{c}\text { Відкритість } \\
\text { досвіду }\end{array}$ \\
\hline Новизна & 0,057 & $-0,036$ & $-0,154$ & 0,163 & $\mathbf{0 , 7 2 0}$ \\
\hline Складність & 0,049 & $\mathbf{- 0 , 2 8 8}$ & 0,085 & 0,202 & $\mathbf{0 , 8 0 7}$ \\
\hline Нерозв'язність & $-0,140$ & $-0,171$ & $\mathbf{0 , 3 1 2}$ & $-0,084$ & $\mathbf{0 , 4 2 8}$ \\
\hline $\begin{array}{l}\text { Усвідомлення своїх } \\
\text { емоцій і почуттів }\end{array}$ & 0,130 & $-0,058$ & $-0,161$ & $-0,105$ & $-0,062$ \\
\hline $\begin{array}{l}\text { Управління своїми } \\
\text { емоціями та почуттями }\end{array}$ & 0,141 & 0,085 & 0,040 & 0,025 & $-0,070$ \\
\hline $\begin{array}{l}\text { Усвідомлення емоцій та } \\
\text { почуттів інших }\end{array}$ & $\mathbf{0 , 2 2 2}$ & 0,113 & $-\mathbf{0 , 3 3 5}$ & $\mathbf{0 , 2 1 0}$ & $-0,092$ \\
\hline $\begin{array}{l}\text { Управління емоціями та } \\
\text { почуттями інших }\end{array}$ & $-0,024$ & 0,110 & $-0,082$ & $\mathbf{0 , 2 0 1}$ & $-0,087$ \\
\hline
\end{tabular}

Відповідно до даних таблиці наявні інтеркореляційні взаємозв'язки всіх шкал методики «Опитувальник великої п’ятірки» зі шкалами толерантності до невизначеності та шкалами міжособистісного аспекту емоційного інтелекту.

Екстраверсія має інтеркореляційні взаємозв'язки із усвідомленням почуттів та емоцій інших $(\mathrm{r}=0,22 ; \mathrm{p} \leq 0,05)$ : комунікабельні особи здатні інтерпретувати емоції та почуття інших людей.

Поступливість має тенденцію до обернених інтеркореляційних взаємозв'язків з усіма складовими толерантності до невизначеності, зокрема iз складністю $(\mathrm{r}=-0,29 ; \mathrm{p} \leq 0,05)$, та тенденцію до прямих інтеркореляційних взаємозв’ язків з усіма шкалами емоційного інтелекту (крім шкали «Усвідомлення 
свої емоцій та почуттів», кореляція 3 якою обернена): поступливі особистості здатні оцінити емоційний стан співрозмовника та управляти свої та чужим емоційним станом, можуть відступити при вирішенні складних завдань.

Сумлінність має інтеркореляційні взаємозв'язки із нерозв'язаністю (r=0,31; $\mathrm{p} \leq 0,05)$ і усвідомленням почуттів та емоцій інших ( $\mathrm{r}=-0,34 ; \mathrm{p} \leq 0,05)$ : сумлінні особи схильні якісно виконувати поставлені перед ними завдання, однак їм складно інтерпретувати емоції та почуття інших людей.

На відміну від поступливості, яка має тенденцію до обернених інтеркореляційних зв’язків 3 усіма шкалами толерантності до невизначеності, відкритість новому досвіду має значущі прямі інтеркореляційні взаємозв'язки 3 цими шкалами: сильні - зі складністю $(\mathrm{r}=0,81 ; \mathrm{p} \leq 0,05)$, новизною $(\mathrm{r}=0,72 ; \mathrm{p} \leq 0,05)$, помірні - 3 нерозв'язаністю $(\mathrm{r}=0,43 ; \mathrm{p} \leq 0,05)$ : відкритих новому досвіду осіб притягують невизначені ситуації, які сприймаються ними як стимулюючі.

\section{Висновки:}

1. Відкритість новому досвіду як особистісна якість науково-педагогічних працівників проявляється у їх професійній діяльності під час міжособистісної взаємодії з учасниками освітнього процесу та при вирішенні складних, нових чи нерозв’язаних завдань навчальної, методичної, наукової, організаційної чи службової діяльності.

2. Науково-педагогічні працівники з різними рівнями відкритості новому досвіду комунікабельні, стійкі до стресу, проявляють низьку особистісну тривожність та толерантність у ситуаціях невизначеності, але відрізняються за показниками сенситивності та емоційної лабільності (межі норми або помірної вираженості), поступливості (конформізм/нонконформізм), показниками шкал міжособистісного аспекту емоційного інтелекту (середня чи низька вираженість його властивостей).

3. Респонденти з високим рівнем відкритості новому досвіду проявляють низьку особистісну тривожність, хорошу комунікабельність та активність, прагнення до самореалізації, демонстративність, стійкість до стресу. Вони мають високий рівень толерантності до невизначеності при вирішенні складних ситуацій та середній - при розв'язанні нових та нерозв'язаних завдань. У спілкуванні можуть проявити конформізм. Схильні до розуміння почуттів та емоції інших людей, але можуть відчувати труднощі в управлінні емоціями співрозмовника.

4. Респонденти 3 середнім рівнем відкритості новому досвіду характеризуються так саме, як і особи 3 високим рівнем відкритості новому досвіду, однак вони схильні не тільки зрозуміти почуття та емоції співрозмовника, а й здійснювати управління ними. У спілкуванні можуть проявити нонконформізм.

5. Респонденти 3 низьким рівнем відкритості новому досвіду характеризуються низькою особистісною тривожністю, комунікабельністю, 
здатністю до співчуття та допомоги іншим, високим рівнем толерантності до невизначеності при вирішенні складних ситуацій та середнім - до невизначеності при розв'язанні нових та нерозв'язаних завдань. Схильні до розуміння почуттів i емоції інших людей та управлінням ними, хоча у спілкуванні можуть проявити нонконформізм.

6. Науково-педагогічні працівники проявляють толерантність у ситуаціях невизначеності: при вирішенні складних завдань здатні бути наполегливими та не поступатись перед труднощами, у випадку нерозв'язаних завдань - схильні проявляти спокій, сумлінність та меншу комунікабельність, але при вирішенні нових для них завдань можуть бути не достатньо ретельними виконавцями.

7. Відкритість новому досвіду зумовлює більшу сконцентрованість науково-педагогічних працівників на накопиченні особистого досвіду вирішення професійних завдань, приділенні більшої уваги інтелектуальній складовій, але зменшення уваги на емоційній складовій міжособистісної взаємодії. Комунікабельність дозволяє краще зрозуміти емоційний стан співрозмовника, низька особистісна тривожність - усвідомити і управляти почуттями та емоціями інших людей, поступливість - оцінити емоційний стан співрозмовника та управляти ним, здійснювати самоконтроль власних емоцій, однак заважає при вирішенні складних завдань; сумлінність - якісно виконувати поставлені завдання, але ускладнює інтерпретацію емоцій та почуттів інших людей.

8. Перспективами подальших наукових досліджень $є$ вивчення особливостей впливу стажу науково-педагогічної діяльності, віку досліджуваних на їх відкритість новому досвіду та підготовка методичних рекомендацій щодо організації підвищення кваліфікації даної категорії осіб із врахуванням отриманих результатів.

\section{Лimepamypa:}

1. Про вищу освіту : Закон України від 01.07.2014 №1556-VII (із змінами і доповненнями). Верховна Рада України. Законодавство України : [сайт]. URL:http://zakon2.rada.gov.ua/laws/ show/1556-18.

2. Про Національну поліцію : Закон України від 2 лип. 2015 р. № 580- VIII. Верховна Рада Украӥни : [сайт]. URL: http://zakon.rada.gov.ua/laws/show/580-19.

3. Барко В. І., Барко В. В., Кирієнко Л. А. Розроблення україномовного опитувальника толерантності до невизначеності для використання в Національній поліції України. Наука $i$ правоохорона. 2019. № 2 (44). C. 223-226. DOI: https: //doi.org.

4. Барко В. І., Остапович В. П., Олешко П. С. Українськомовна адаптація опитувальника рівня і структури емоційного інтелекту з метою психологічного добору поліцейських. Психологічний журнал. 2019. № 3 (23). C. 9-25. DOI: https://doi.org/10.31108/1.2019.3.23.1

5. Білогурова С. В., Барко В. І., Барко В. В., Кирієнко Л. А. Адаптація «Індивідуальнотипологічного опитувальника» для використання при проведенні конкурсу на службу до поліції. Наука і правоохорона. 2017. № 3 (37). С. 219-228.

6. Барко В. І., Остапович В. П., Барко В. В. Можливості використання «Опитувальника великої п’ятірки» психологами Національної поліції України. Науковий вісник Херсонського державного університету. Серія Психологічні науки. 2018. Вип. 3. Т. 2. С. 181-186. 
7. Ілляхова М. В. Інноваційна діяльність у структурі креативності науковопедагогічних працівників. Молодий вчений. 2019. № 2 (66). С. 101-105. DOI: https://doi.org/10.32839/2304-5809/2019-2-66-23 УДК 37.014.53.

8. Ілляхова М. В. Структура креативності науково-педагогічного працівника. Педагогічні науки : зб-к наук-х пращьь. 2019. № 87. C. 52-57. DOI: https://doi.org/10.32999/ ksu2413-1865/2019-87-8.

9. Матюшкина А. А. Открытость новому опыту как личностная предпосылка творческого мышления. Вестник Московского городского педагогического университета. Серия: Педагогика и психология. 2014. № 3 (29). С. 32-42.

10. Тімченко О. В., Самохвалов О. Б. Креативність як інваріанта професіоналізму співробітників правоохоронних органів. Вісник Національної академії Державної прикордонної служби Украӥни. Психологічні науки. 2014. Вип. 4. URL: http://repositsc.nuczu.edu.ua/bitstream/ 123456789/2432/1/Vnadps_2014_4_22.pdf.

11. Чуприна Ю. А. Професійний розвиток науково-педагогічних працівників. Трудове право; право соціального забезпечення : автореф. дис. ... канд. юрид. наук : 12.00 .05 / Нац. юр. ун-т ім. Ярослава Мудрого. Харків, 2021. 23 с.

\section{References:}

1. Pro vyshhu osvitu: Zakon Ukrajiny vid 01.07.2014 № 1556-VII (iz zminamy i dopovnennjamy) [On higher education: Law of Ukraine of 01.07.2014 №1556-VII (with changes and additions)]. zakon.rada.gov.ua. Retrieved from http://zakon2.rada.gov.ua/laws/show/1556-18 [in Ukrainian].

2. Pro Nacionaljnu policiju: Zakon Ukrajiny vid 2 lyp. 2015 r. № 580- VIII [On the National Police: Law of Ukraine of July 2. 2015 № 580- VIII]. zakon.rada.gov.ua. Retrieved from http://zakon.rada.gov.ua/laws/show/580-19 [in Ukrainian].

3. Barko, V. I., Barko, V. V. \& Kyrijenko, L. A. (2019). Rozroblennja ukrajinomovnogho opytuvaljnyka tolerantnosti do nevyznachenosti dlja vykorystannja v Nacionaljnij policiji Ukrajiny [Development of a Ukrainian-language uncertainty tolerance questionnaire for use in the National Police of Ukraine]. Nauka i pravookhorona - Science and law enforcement, 2 (44), 223-226 DOI: https: //doi.org [in Ukrainian].

4. Barko, V. I., Ostapovych, V. P. \& Oleshko, P. S. (2019). Ukrajinsjkomovna adaptacija opytuvaljnyka rivnja i struktury emocijnogho intelektu z metoju psykhologhichnogho doboru policejsjkykh [Ukrainian-language adaptation of the questionnaire on the level and structure of emotional intelligence for the purpose of psychological selection of police officers]. Psykhologhichnyj zhurnal - Psychological Journal, 3 (23), 9-25 DOI: https://doi.org/10.31108/1.2019.3.23.1 [in Ukrainian].

5. Biloghurova, S. V., Barko, V. I., Barko, V. V. \& Kyrijenko, L. A. (2017). Adaptacija «Indyvidualjno-typologhichnogho opytuvaljnyka» dlja vykorystannja pry provedenni konkursu na sluzhbu do policiji [Adaptation of the "Individual-typological questionnaire" for use in the competition for service in the police]. Nauka i pravookhorona - Science and law enforcement, 3 (37), 219-228 [in Ukrainian].

6. Barko, V. I., Ostapovych, V. P. \& Barko V. V. (2008). Mozhlyvosti vykorystannia «Opytuvalnyka velykoi piatirky» psykholohamy Natsionalnoi politsii Ukrainy [Possibilities of using the "Big Five Questionnaire" by psychologists of the National Police of Ukraine]. Naukovyi visnyk Khersonskoho derzhavnoho universytetu - Scientific Bulletin of Kherson State University, issue 3 (Vols. 2), 181-186 [in Ukrainian].

7. Illjakhova, M. V. (2019). Innovacijna dijaljnistj u strukturi kreatyvnosti naukovopedaghoghichnykh pracivnykiv [Innovative activity in the structure of creativity of scientific and pedagogical workers]. Molodyj vchenyj - A young scientist, 2 (66), 101-105. DOI: https://doi.org/10.32839/2304-5809/2019-2-66-23 UDK 37.014.53 [in Ukrainian]. 
8. Illjakhova, M. V. (2019). Struktura kreatyvnosti naukovo-pedaghoghichnogho pracivnyka [The structure of creativity of the scientific and pedagogical worker]. Pedaghoghichni nauky - Pedagogical sciences, 87, 52-57. DOI: https://doi.org/10.32999/ksu2413-1865/2019-87-8 [in Ukrainian].

9. Matjushkyna, A. A. (2014). Otkrytostj novomu opytu kak lychnostnaja predposylka tvorcheskogho myshlenyja [Openness to new experience as a personal prerequisite for creative thinking]. Vestnyk Moskovskogho ghorodskogho pedaghoghycheskogho unyversyteta - Bulletin of the Moscow City Pedagogical University, 3 (29), 32-42 [in Russian].

10. Timchenko, O. V. \& Samokhvalov, O. B. (2014). Kreatyvnistj jak invarianta profesionalizmu spivrobitnykiv pravookhoronnykh orghaniv [Creativity as an invariant of the professionalism of law enforcement officers]. Visnyk Nacionaljnoji akademiji Derzhavnoji prykordonnoji sluzhby Ukrajiny - Bulletin of the National Academy of the State Border Guard Service of Ukraine, issue 4. Retrieved from http://repositsc.nuczu.edu.ua/bitstream/123456789/2432/1/ Vnadps_2014_4_22.pdf [in Ukrainian].

11. Chupryna, Ju. A. (2021). Profesijnyj rozvytok naukovo-pedaghoghichnykh pracivnykiv. Trudove pravo; pravo socialjnogho zabezpechennja [Professional development of scientific and pedagogical workers. Labor Law; social security law]. Extended abstract of candidate's thesis. Kharkiv: Nac. jur. un-t im. Jaroslava Mudrogho [in Ukrainian]. 